\title{
SEEDS OF QUAKERISM AT THE ROOTS OF LEAVES OF GRASS
}

\author{
SUSAN DEAN
}

FOR SOME TIME I have been tracing out the relations between Quaker culture and Leaves of Grass. It began ten years ago, when I read a long selection from the fournal of fohn Woolman, the eighteenth-century New Jersey Quaker, and was struck by similarities in the monistic imagery and in the verbal syntax of Woolman and of Whitman. ${ }^{1}$ Whitman himself was not a member of the Society of Friends, but he had known Quaker language and traditions through his mother and his maternal grandmother. Could there be an unconscious influence, or even a conscious borrowing, there?

By turning this question into a working hypothesis, $I$ have found that it brings into suggestive light several references to Quakerism in Whitman's later prose writings, references that encouraged me to do research into Quaker ideas and history. ${ }^{2}$ In the essay that follows I will present some of the Quaker concepts that are directly relevant to the vision of democracy that Whitman wanted to promote through his poetry. I then turn to other concepts that he did not or could not draw from Quakerism, concepts whose absence leaves his democratic programme partial and unfinished.

More undogmatic, open, and tolerant than other versions of Christianity, Quakerism's simple statement of belief ("There is 'that of God" in Every Person") articulated an equalizing quality in all human beings (residing in a "soul," an inner light) that offered a conceptual basis for the equality of all citizens in a mass-democracy, a concept that would have been of the utmost usefulness to Whitman. ${ }^{3}$

This Quaker belief lies behind two references that Whitman made in his prose to the once-notorious refusal of English Quakers to tender (or to accept) "hat-honor" as a mark of selective deference, since such honor belonged only to the Holy Spirit itself, present in all living beings. Whitman announces this principle forthrightly in his 1855 Preface to the first edition of Leaves, setting it prominently in the list of habits that he tells the reader to follow: "take off your hat to nothing known or unknown or to any man or number of men." ${ }^{4}$ I link this injunction to a remark Whitman makes later in the Preface, defining "the affluent man": 
The most affluent man is he that confronts all the shows he sees by equivalents out of the stronger wealth of himself. ( $L G 718$ )

This definition has occasioned much critical speculation as to the psychological and philosophical basis for Whitman's proud faith in the human self. By viewing it in the context of the piety that motivated Quaker hat-honor, we make visible a spiritual dimension that is often missed by critics of Whitman's "secular humanism."

Forty-five years after writing the Preface, when Whitman looks back over his poetic career and purposes in "A Backward Glance O'er Travel'd Roads," he constructs a puzzle for his reader out of hat-honor refusal. As a young man, says Whitman, he used to read the great poetical works that Americans had inherited from the Old World-the Bible, Shakespeare, Ossian, Dante, Greek epic and drama, Hindu poetry. Indeed, he says, he was able to write Leaves of Grass only because he stood before "those poems with uncover'd head, fully aware of their colossal grandeur and beauty of form and spirit" ( $L G 568)$. This little autobiographical detail, with its commentary, seems directly at odds with a cultural criticism offered to the reader elsewhere in "A Backward Glance": namely, that all of the great art works imported from the Old World carry within themselves an implicit "denial and insult to [American] democracy" ( $L G 567$ ). How then does Whitman explain his ability in his early years to shrug off the colonizing shadow cast by past excellence?

(I have wonder'd since why I was not overwhelm'd by those mighty masters. Likely because I read them . . . in the full presence of Nature, under the sun, with the farspreading landscape and vistas, or the sea rolling in.)

And he nudges us further: "it makes such difference where you read" (LG 569).

The answer to the puzzle lies in the willful turns that are possible in hat-honor refusal; it lies, too, in this early boast in "Song of Myself": "I wear my hat as I please indoors or out" ( $L G 47)$. Thus when Whitman is alone outside, in the scenery of the New World, facing the great books he has brought out with him, it pleases him to remove his hat, not to those books but to the great sky above him and them, and to the rolling wind of Creation that moves the forms of language and life alike.

A second quality associated with Quakers is a distinctive and positive view of silence, due to their belief in a "that of God" within all forms of Creation. Rather than being a void or an emptiness, that which utterance is defined against, silence in their view is the source of all forms of utterance- $a$ womb of fullness to which human beings may return again and again for inspiration. Such a belief accords well with Whitman's own leveling views of writing, reading, speaking, and silent listening. Whitman is struggling to arrive at this view in "Song of the 
Rolling Earth," an 1856 poem in which he is trying to reconcile his ideal of complete sexual candor with his (then) sense of not having found the right time, mode, and degree of utterance. By 1865, five years after his publication of the Children of Adam and Calamus poems, he has found his means of utterance, and he is able to write of silence as something "perfect" in "When I Heard the Learn'd Astronomer" ( $L G$ 271).

In the forms articulated by George Fox in seventeenth-century England and Elias Hicks in nineteenth-century United States, Quakerism was conscious of being a minority culture, since the beliefs about human nature that it promoted ran counter to those of the majority culture that established commonsense orthodoxy for most of the English-speaking world. ${ }^{5}$ Orthodox culture perpetuated, and profited from, dualistic visions of creation (supernatural heaven vs. supernatural hell, with "nature" falling somewhere in between) and of human nature (radically flawed with "original sin," incapable of self-control and needing external restriction from social institutions such as royalty, aristocracy, universities, armies, police, churches, priests). Within this larger culture, Quakers pictured themselves as seeds, working through non-violent persuasion, showing by example that human nature, along with all the rest of created nature, carried within itself a seed of "that of God" that gave it an undying potential for goodness and happiness.

In my judgment, "A Memorandum at a Venture," Whitman's 1882 essay defending his frankly sexual lyrics in the 1860 Leaves, is his clearest expression and extension of this Quaker affirmation of nature. The "Memorandum" argues for the divinely-created, divinely-ordered nature of human sexuality, and calls for a third, alternative point of view, breaking free of the oppositions between Puritanism and prurience-a view that accepts sexuality and treats it candidly:

Through precept and consciousness, man has long enough realized how bad he is. I would not so much disturb or demolish that conviction, only ... resume and keep unerringly with it the spinal meaning of the Scriptural text, God overlook'd all that He had made (including the apex of the whole - humanity - with its elements, passions, appetites,) and behold, it was very good.

Does not anything short of that third point of view, when you come to think of it profoundly and with amplitude, impugn Creation from the outset? ... does not the conviction involv'd in it perennially exist at the center of all society, and of the sexes, and of marriage? Is it not really an intuition of the human race?

In this essay, Whitman takes a fundamental attitude in Quakerism (that all of creation is divine in its bases, its eligibilities, and evil is a perversion of the good), and stretches it beyond what was then Quaker orthodoxy, to affirm that the entire continuum of human sexuality is "natural" and that all of its "elements, passions, appetites," must be accepted as a whole; to do otherwise is to impugn Creation and to fall short of the full monistic faith of Quakerism. 
The Quakers believed that "that of God" was planted in the human soul to give it the centering and balance it needed to fit in with the purposes of creation. This belief led them to the conviction that human egotism, malice, and evil were the results of off-centering, in which the divine seed was crowded to the side. But the seed lives on always, and with proper cultivation, from a culture of love that encouraged listening to the internal promptings of the soul rather than resorting to external force, the soul would yield the seed the central place created for it, and thus would be restored to its "natural" goodness.

This is the dynamic Whitman describes at work in his 1888 essay on "George Fox (and Shakspere)," where in three paragraphs he summarizes Fox's remarkable life as a religious teacher. During a time of religious upheavals in England Fox goes off into the hills and fields to seek a truth he can put his faith in. He finds it in the direct inspiration of the Holy Spirit within each soul, and he returns to testify to this truth again and again in towns and villages, despite "ridicule, whipping, imprisonment." But Fox and his simple but radical message are irrepressible; and gradually, says Whitman, "one or two here, and three or four there," and eventually thousands, "catch the contagion" of his views, persisting in that spirit until their Society of Friends earns a tolerated place among the religious sects of the world ( $P W 2: 652)$.

I contend that in Leaves of Grass, and especially in the "Calamus" poems, Whitman is trying to win for the gay minority in nineteenthcentury America what the Quaker minority had won in England in the seventeenth. ${ }^{7}$ For forty years the Quakers, the "Friends of Truth," conspicuously displayed the signs of their "Friendly Persuasion" in public: insisting on dressing differently from their neighbors; insisting on addressing everyone with the familiar pronouns, "Thee" and "Thou," to express shared subjectivity; refusing to remove their hats to social superiors in public; refusing to swear oaths or to serve in the army or to pay war taxes. After forty years the authorities and the English public gave way, as it became clear that these disturbing practices followed a principle that would be held to despite unremitting, and unresisted, punishment. The Act of Toleration that was passed in 1689 recognized and affirmed the right of Friends to practice their unorthodox faith openly.

Like the seventeenth-century Quakers, Whitman set out to enact in public his version of "Friendly Persuasion": writing and publishing poems in which young men signaled in their actions the love they enjoyed for one another, poems which worked to enlist public sympathy and to dispel reactions of shock and disapproval.' Calamus has many "performative" poems that carry out this intention to stretch the boundaries of public tolerance. Here are just three of them that set forth a programme to "naturalize" expressions of same-sex affection. First, in "What Think You I Take My Pen in Hand?": 
What think you I take my pen in hand to record?

The battle-ship, perfect-model'd, majestic, that I saw pass the offing to-day under full sail?

No, says the poet:

But merely of two simple men I saw to-day on the pier in the midst of the crowd, parting the parting of dear friends,

The one to remain hung on the other's neck and passionately kiss'd him,

While the one to depart tightly prest the one to remain in his arms. ( $L G 133$ )

Next, from "A Leaf for Hand in Hand":

A leaf for hand in hand;

You natural persons old and young!

You on the Mississippi and on all the branches and bayous of the Mississippi!

You friendly boatmen and mechanics! you roughs!

You twain! and all processions moving along the streets!

I wish to infuse myself among you till I see it common for you to walk hand in hand. ( $L G$ 132)

When such attitudes and behavior become commonplace, then the ideal of love that in William Penn's Quaker city of brotherly love, Philadelphia, is only partially, only spiritually, realized, will come into fullydimensional being. We see this third step in "I Dream'd in a Dream":

I dream'd in a dream I saw a city invincible to the attacks of the whole of the rest of the earth,

I dream'd that was the new city of Friends,

Nothing was greater there than the quality of robust love, it led the rest,

It was seen every hour in the actions of the men of that city,

And in all their looks and words. ( $L G$ 133)

Because "that of God within" takes new forms, gives new illumination, with each new life, a way is cleared for change and evolution in the group's vision of new possibilities and forms for goodness. At the same time, strictness and self-reproach over the shortcomings of visions of the past are made unnecessary; such self-forgiveness comes with the Quaker understanding that, as tiny active particles of the creative process, Friends cannot expect to "divine" and comprehend the whole, only what lies within their scope. Thus their optimism: they are enabled to be "at ease outside of Zion," at home with their own imperfect vision.

This attitude accords with the serene persona that confronts the reader of "Song of Myself"-the "Me, Imperturbe," in passages like these: 
Showing the best and dividing it from the worst age vexes age,

Knowing the perfect fitness and equanimity of things, while they discuss I am silent, and go bathe and admire myself. ( $L G 31$ )

And I say to mankind, Be not curious about God,

For I who am curious about each am not curious about God,

(No array of terms can say how much I am at peace about God and about death.).

( $L G$ 86)

Such equanimity, a chord maintained through the various editions of Leaves of Grass, disappears from the register of Democratic Vistas (18701871), when Whitman is watching the newly re-United States move decisively toward an imperial "destiny." But he returns to it more fully than ever in "A Backward Glance" in 1889, with a final expression of belief that strikes that Quaker chord of faith in Creation:

Then still a purpose enclosing all, and over and beneath all . . . I felt it all as positively then in my young days as I do now in my old ones; to formulate a poem whose every thought or fact should directly or indirectly be or connive at an implicit belief in the wisdom, health, mystery, beauty of every process, every concrete object, every human or other existence, not only consider'd from the point of view of all, but of each. ( $L G$ 572-573)

The word "positively" might lead us to think we hear a claim of certain knowledge and a denial of contradictory perceptions in the hope expressed. But what gives this hopefulness a Quaker character is the word "felt" that soulfully qualifies, relativises the positivism, makes it a statement of faith rather than of possessed knowledge. Also there is that odd word "connive"; I think it expresses a Quaker-like awareness of how much our individual subjectivities contribute to our view of "objective reality" and how much we help one another "keep hope alive," maintaining the faith of our respective faith-communities.

I turn now to elements of Quaker culture that were not incorporated into Whitman's vision of democracy. First of all, Whitman seems to have lacked knowledge and curiosity about egalitarian group-structures in the Society of Friends: the authority based in local neighborhood meetings; the rotating arrangement by which local meetings met for worship and business without permanent (or paid) ministers; the way that meetings worked through dissenting views in their search for consensus; the way that local meetings acted as extended families, taking on burdens that individual members would need help with when following the lead of their consciences. Instead, Whitman was interested in describing the individual lives of Quaker teachers like Hicks and Fox. And in their lives he focused not on the ongoing results of their social reforms but on their willingness to remain steadfast in, and endure censure for, their non-conformist testimonv. He denicts them as 
inspired individuals making their way through the confusions and choices of the world by the promptings and "divinings" of their inner naturesrather like himself.

What we miss in Whitman is a concern (even a curiosity) about social organizations that might be more fostering of democracy than our national government is able to be with its impersonal structures, and more in keeping with the "grass-roots" rhizome-like structure of the Leaves: non-hierarchical, adaptive, able to respond to change by withdrawing, going under, emerging unpredictably from underground. Had Whitman had practical knowledge of Quaker organization when he was revising Democratic Vistas for publication in 1871 , he might have gone beyond that essay's vision of a democracy of friends ( $P W 2: 414$ ), in which individual souls $(P W 2: 411)$ circle in orbit through the cosmos that they know as the All $(P W 2: 418,420)$, turning from one pairing to another in loving friendship ( $P W 2: 414-415 n)$. As a whole the dancing circle is beautiful, but because the relating is transitory and dyadic only, it makes us look again critically at the evanescence of the roots and lateral connections in Whitman's poems. The only support that Whitman can envision for his souls are "literatuses"-culture-agents, teachers, and artists of the divine in human nature, who can sing them into some kind of loving order (PW 2:421).

A second element missing from Whitman's vision of democracy is economic egalitarianism. This absence, also, can be traced to the partial nature of his knowledge of the Society of Friends. Whitman uses a brookimage for Elias Hicks throughout his 1888 essay: like "little rills of water, fresh, from perennial springs," "a little flowing liquid rill of Nature's life, maintaining freshness" (PW 2:644) and "pointing to the fountain of all ... religion," "inside of man's very own nature." He, Whitman, like a wanderer who has come upon a clear cool unpolluted brook in the woods, will make a cross-notched mark to remind himself and others that Hicks, like Fox before him, represents "a matter of first-rate importance and full investigation." Full investigation is needed because the "Democratic Institutes of the United States" (PW 2:647) with their overly external focus upon "business, politics, competition, practical life" (PW 2:638-639), have obscured from their view, and from view of their citizens, the originating location of "the living fountains of belief" ( $P W 2: 647$ ) - within each human soul. ${ }^{8} \mathrm{I}$ read the Hicks essay, then, as another attempt by Whitman to apply Quaker culture as a democratizing corrective: here, an "antiseptic" (PW 2:638) to cool the fevers of capitalism that he thought had seized and blinded democracy in his lifetime. Again, I argue that the attempt is unsuccessful because Whitman lacked awareness of the group nature of the economic reforms promoted by American Quakers such as Hicks and Woolman. For explanation, let us go once more into Quaker history. 
Quakerism had been careful to distinguish itself from other revolutionary sects that set themselves against Establishment hierarchies in the 1640s. The Friends insisted on the separation of Church and State, refusing to conform to government edicts that violated principles of their faith but, unlike the anarchistic Ranters, obeying all other rulings. And unlike the socialistic Diggers, Friends were not interested in asserting that the land and its resources should be held in common, nor in challenging private property as an institution. Instead, they voluntarily took it upon themselves to live lives of simplicity, so as to mediate between the social extremes of poverty and riches.

In refusing to adopt, as other radically democratizing movements were adopting, a political and economic dimension to their egalitarianism, the seventeenth-century Quakers had emphasized the spiritual, psychological, and individual aspects of their faith-testimony. ${ }^{9}$ But this emphasis was not meant to be final, for revelation was open-ended and so new understandings of truth were possible. After the seventeenthcentury, Quakers did indeed begin to address large economic problems in their testimonies, especially in English-speaking America where they could see the problems taking effect: in the eighteenth century John Woolman testified against owning slaves; in the nineteenth Elias Hicks spoke out against even dealing in goods produced by the labor of slaves; and both men persuaded their meetings to take concerted action, as a group.

However, this later turn, in which spiritual testimony necessarily includes economic testimony, has been an individual choice rather than general practice in the Society of Friends, and so it has not become etched into the pattern by which Quakerism is generally known. In the history that all Friends can agree upon, individuals have traditionally been encouraged to live simple lives and to set limits to desires, promoted by the larger culture, for accumulating property and wealth; but they are not taught to question the institution of private property itself. Since Whitman's vision of American democracy also accepts the private ownership of property as a necessary basis for civil society, we see that for him, the Quaker pattern would have had political activism coexisting with economic conservatism. One of the "Calamus" poems, "I Hear It Was Charged Against Me," is a fine example of this combination of attitudes:

I hear it was charged against me that I sought to destroy institutions,

But really I am neither for nor against institutions,

(What indeed have I in common with them? or what with the destruction of them?)

Only I will establish in the Mannahatta and in every city of these States inland and seaboard,

And in the fields and woods, and above every keel little or large that dents the water, 
Without edifices or rules or trustees or any argument, The institution of the dear love of comrades. ( $L G$ 128)

Time has shown that Quaker principles and practice have not been able to win the majority away from the prevailing world-view that equates wealth with happiness, the institution of private property with the institution of the dear love of comrades. Quakerism has kept to its principle of individual self-control and voluntary simplicity. Its faithfulness to this principle may have contributed to its permanent minority status: more than tolerated, it is even regarded by the majority with affectionbut from a distance, so that its ideas and their interconnections are not understood or taken seriously.

Whitman was aware of these dismissive attitudes when he wrote his 1888 essays on Hicks and Fox. He would have seen the parallels between the voluntary simplicity that was Quaker culture's best answer to the problems of economic injustice and his own life's answer to the question he had posed in Democratic Vistas, "who [shall] bridle leviathan?" (PW 2:422). (You and I, dear reader, one by one infecting others with our "germinal" lives of natural simplicity, natural sufficiency, loving friendship.) By 1888 , then, he was realizing that the democratic principles he shared with this "obscure" set might win only as much popular acceptance as theirs had-that is, a distanced recognition and toleration. Whitman's conclusion to the Hicks essay invokes a cosmic image that seems relevant to the issue of popular acceptance. He pictures above in space, co-existing alongside the perceptible stars, other "dark," impalpable ones, unreckoned except by astronomers, invisible to eyes conditioned by the "lexicon of brightness" by which the spreading heavens have been mapped ( $P W 2: 649$ ). In 1888 the lexicon still awaited new words that could bring obscured realities into view.

Of course, Quakerism was only one of the cultures that Whitman drew upon for his democratizing in Leaves of Grass. But the exercise of examining the complex movement of ideas and images from even one culture can yield findings that illuminate Whitman's cultural borrowings in general. Here, for example, are two general propositions from this inquiry that can serve as working assumptions for other influencestudies:

First: In seeking to understand Whitman's democratic vision, we should give full weight to his claims that religion plays an important part in it, rather than dismissing them because of the secular and/or sentimental qualities in his faith-statements.

Second: It seems to be the case with cultural influence and confluence that features characteristically present in the culture borrowed-from (such as Quakerism's policy of hat-honor), as well as features historically absent from it (Quakerism's reluctance to challenge 
the institution of private property), will silently affect the blended product that results, emerging into later view as anomalies. Studies that approach a work like Leaves of Grass as the product of one culture and one individual will treat such anomalies as marks of individual eccentricity or genius. But when we adjust our lenses to view the work as one that includes conscious and unconscious exchanges mediated by an individual at a cultural intersection (in Whitman's case, a cosmic intersection!), the anomalies become opportunities for us to trace cross-cultural conversations and even to reach in and extend them further, a freedom that Whitman repeatedly invites us to exercise.

\section{Bryn Mawr College}

\section{NOTES}

1 John Woolman, The fournal and Major Essays of fohn Woolman, ed. Phillips P. Moulton (Richmond, Indiana: Friends United Press, 1971).

2 Some other critics who have explored the influence of Quakerism upon Whitman are W. B. Fulghum, Jr., "Quaker Influences on Whitman's Religious Thought" (Unpublished doctoral dissertation, Northwestern University, May 1943); Robert Duncan, Fictive Certainties (New York: New Directions, 1955); Daniel B. Shea, Jr., Spiritual Autobiography in Early America (Princeton: Princeton University Press, 1968).

3 For assessments of this influential belief, see Howard Brinton, Friends for 300 Years: The History and beliefs of The Society of Friends since George Fox started the Quaker movement (Wallingford, PA: Pendle Hill Publications, 1952); and Richard Bauman, Let Your Words Be Few: Symbolism of Speaking and Silence Among Seventeenth Century Quakers (Cambridge: Cambridge University Press, 1983).

4 Leaves of Grass, Comprehensive Reader's Edition, ed. Harold W. Blodgett and Sculley Bradley (New York: New York University Press, 1965), 715.

5 For a thorough account of the Society's perception of itself as a minority group, and of the actions it took to get its own view of itself out to the majority, see Luella $M$. Wright, The Literary Life of The Early Friends, 1650-1725 (1932; rpt. AMS Press, 1966).

6 Prose Works 1892, ed. Floyd Stovall. Vol. 2: Collect and Other Prose (New York: New York University Press, 1964), 496-497.

7 I draw on two historians for my argument that Whitman was consciously seeking to win for gay culture the public toleration that Quaker culture had won: Randolph Trumbach, "The Birth of the Queen: Sodomy and the Emergence of Gender Equality in Modern Culture, 1660-1750," in Hidden from History: Reclaiming the Gay and Lesbian Past, ed. Martha Vicinus and George Chauncey, Jr. (New York: Penguin, 1989), 129-140; and Stuart Hall, "Deviance, Politics, and the Media," in The Lesbian and Gay Studies Reader, ed. Henry Henry Abelove, Michéle Aina Barale, and David M. Halperin (New York: Routledge, 1993), 62-90.

8 For phrases quoted from "Elias Hicks" without citation, see $P W 2: 627 \mathrm{n}$.

9 Christopher Hill analyzes the characteristics that set apart the spiritual radicalism of the Friends from the legal radicalism of the Ranters and the economic radicalism of the Diggers, making them more acceptable to the authorities in seventeenth-century 
England. See The World Turned Upside Down: Radical Ideas during the English Revolution (New York: Viking Penguin, 1972). 